\title{
Properties of a Proteus morganii Bacteriocin
}

\author{
By J. A. SMIT \\ Division of Life Sciences, Atomic Energy Board, Pretoria \\ AND H. C. DE KLERK AND J. N. COETZEE \\ Department of Microbiology, University of Pretoria, Pretoria, South Africa \\ (Accepted for publication I June 1968) \\ SUMMARY \\ The bacteriocin produced by Proteus morganii strain MR 336 is a thermo- \\ labile glycoprotein with a sedimentation constant of $4^{\circ} 0$. Activity is depen- \\ dent on the integrity of the complex and the bacteriocin is inactivated by \\ oxidation. Bacteriocinogeny could not be transmitted to other strains of \\ $P$. morganii but was eliminated by $30 \mu \mathrm{g}$. $/ \mathrm{ml}$. acridine orange at $\mathrm{pH} 7 \cdot 45$. \\ Bacteriocin-resistant mutants of a sensitive $P$. morganii strain were readily \\ obtained.
}

\section{INTRODUCTION}

Investigations of the chemical nature of bacteriocins have shown them to be a heterogeneous group of macromolecular substances ranging from simple proteins (Holland, 196r; Herschman \& Helsinki, 1967) which may be complexed to carbohydrate and lipids (Goebel \& Barry, I958; de Klerk \& Smit, 1967) to particles of high molecular weight which resemble phages (Endo, Ayabe, Amako \& Takeya, 1965; Sandoval, Reilly \& Tandler, 1965) or parts of phages (Ishii, Nishi \& Egami, 1965; Coetzee, de Klerk, Coetzee \& Smit, 1968). The chemical nature of the association between lipopolysaccharide and protein is unknown but the biological activity of bacteriocins is always associated with the protein component (see Nomura, 1967) and it is this protein and not the lipopolysaccharide which is genetically controlled by the bacteriocinogenic factors in Escherichia coli (Hinsdill \& Goebel, 1966). In E. coli bacteriocinogenic factors are called colicinogenic or col factors. Col factors may be transmitted from cell to cell by direct contact (Frédéricq, 1954) and may then act as sex factors in that they effect chromosomal transfer between bacterial cells (Ozeki \& Howarth, 1961 ; Smith \& Stocker, 1962). The col factors are considered to be plasmids (Lederberg, 1952; Nomura, 1967). The nature of factors which control bacteriocinogeny in other species is unknown. Coetzee (1967) described bacteriocinogeny in strains of Proteus morganii and it was decided to investigate one of them. The choice fell on the bacteriocin produced by $P$. morganii strain MR 336 because it can be obtained consistently in reasonable titre by ultraviolet induction of broth cultures of the organism and it differs from the other $\boldsymbol{P}$. morganii bacteriocins in being more mobile on agar electrophoresis (H. L. Coetzee \& I. J. Maré, unpublished observations). This bacteriocin, which is now called 336 , kills 31 of 94 different isolates of $P$. morganii but has no inter-species activity (Coetzee, 1967). 


\section{METHODS}

Media. The solid medium was Difco MacConky agar. The broth was Difco brain heart infusion and also this broth freed of high molecular weight constituents by dialysis under negative pressure (de Klerk \& Smit, 1967). When needed, streptomycin sulphate (I $\mathrm{mg} . / \mathrm{ml}$.) was added to solid media. The fluid medium used for acridine orange (Edward Gurr, London) treatment was that of Hirota (I960).

Bacterial strains. The bacteriocinogenic Proteus morganii strain MR 336 and $P$. morganii indicator strain MR 47 for this bacteriocin have been described (Coetzee, 1967).

Proteus morganii strains NM 107 and NM I I6, which are susceptible to the bacteriocins liberated by strains MR 336, NM 38 and NCTC $28 \mathrm{I} 8$, were used in experiments to obtain mutants resistant to bacteriocin 336. Streptomycin resistant (str-r) mutants of $P$. morganii strains NM 154 and NCTC 5845 were used as recipients in attempts to transfer bacteriocinogeny from strain MR 336. These strains are not susceptible to bacteriocin 336. Strains were maintained on nutrient agar slopes at $4^{\circ}$. Incubation was at $37^{\circ}$.

Production of bacteriocin. Crude bacteriocin was obtained by ultraviolet induction of strain MR 336 in broth diffusate by the method of Coetzee et al. (1968). Irradiated cultures were sterilized with chloroform, centrifuged and the supernatants assayed.

Assay of bacteriocin. This was done by a spotting technique (Coetzee, 1967). The highest inhibitory dilution was the titre.

Bacterial mutants resistant to bacteriocin 336. Overnight broth cultures of strains NM 107 and NM I I 6 were plated ( $0.1 \mathrm{ml}$.) and, when dry, drops of high titre bacteriocin 336 ( $>$ I/I000) were spotted on the lawn. Plates were incubated and colonies which arose within the areas of bacteriocin inhibition were picked off and streaked on to agar. Purified colonies were subsequently tested for susceptibility to bacteriocin 336 and bacteriocins produced by strains NM 38 and NCTC 2818 by the agar streak method (Coetzee, 1967).

Transfer of bacteriocinogeny. This was attempted by the method of Ozeki, Stocker \& Smith (1962) and Smith, Ozeki \& Stocker (1963). After $24 \mathrm{hr}$ incubation the mixed cultures of MR 336 and NM I 54 str-r and also MR 336 and NCTC 5845 str-r were plated on streptomycin agar. After $48 \mathrm{hr}$ incubation colonies were transferred to agar slopes. Streaks of these cultures were then tested for bacteriocin production with the use of an ultraviolet induction technique and indicator strain MR 47 (Coetzee, I967). This cumbersome method was used as bacteriocin 336 is inducible (Coetzee, 1967) and control experiments proved it to be the most reliable.

Exposure of strain MR 336 to acridine orange. This was done according to Kahn \& Helinski (1964). The concentration of acridine orange varied from 0 to $70 \mu \mathrm{g} . / \mathrm{ml}$. at $\mathrm{pH}$ values between $7 \cdot 0$ and $7 \cdot 8$. After the treatment dilutions of the cultures were plated and incubated. Colonies which arose were tested by the streak induction method (Coetzee, 1967) for bacteriocinogeny.

Purification of bacteriocin. Solid EDTA and sodium sulphite were added to crude preparations of bacteriocin in a final concentration of $0.00 \mathrm{I}$ and $0.05 \mathrm{M}$ respectively. Activity was precipitated by addition of solid ammonium sulphate to ice-cold solutions of bacteriocin to a saturation of $50 \%$ and the precipitate deposited by centrifugation $(40,000 \mathrm{~g}$ for $\mathrm{I} 5 \mathrm{~min}$.) after standing $\mathrm{I} 6 \mathrm{hr}$ in the cold. The pellets were dissolved in $0 . \mathrm{I} \mathrm{M}-\mathrm{KCl}+0.05 \mathrm{M}$-tris- $\mathrm{HCl}+0.05$ M-sodium sulphite + 0.00I M-EDTA buffer ( $\mathrm{pH} \mathrm{7.6)}$ and centrifuged ( $105,000 \mathrm{~g}$ for $\mathrm{I} 5 \mathrm{~min}$.). The supernatant was filtered through What- 
man no. I paper and concentrated by dialysis under negative pressure in the cold. Samples (2.5 ml., equivalent to I 1 . crude bacteriocin solution) of the non-diffusible material were applied to columns $(2.5 \mathrm{~cm} . \times 50 \mathrm{~cm}$.) containing Sephadex G 200 and eluted with $0.1 \mathrm{M}-\mathrm{KCl}+0.05 \mathrm{M}$-tris- $\mathrm{HCl}+0.05 \mathrm{M}$-sodium sulphite $+0.00 \mathrm{I}$ M-EDTA buffer $(\mathrm{pH} 7 \cdot 6)$ at a flow rate of $5 \mathrm{ml}$./hr. Column effluents were collected in $5 \mathrm{ml}$. fractions and assayed for activity and the optical density at $280 \mathrm{~m} \mu$ determined. High titre fractions were pooled and concentrated by dialysis under negative pressure in the cold. The dialysis residue $(2.5 \mathrm{ml}$., equivalent to I 1 . crude bacteriocin solution) was dialysed against Io mM-sodium phosphate buffer, $\mathrm{pH} 6 \cdot 8$ and applied to a chromatography tube $(1 \mathrm{~cm} . \times$ IO $\mathrm{cm}$.) containing calcium phosphate gel (Tiselius, Hjertén \& Levin, 1956). Step-wise elution was carried out with I0, 50, 100, 200 and $400 \mathrm{mM}$ sodium phosphate buffer solutions, pH 6.8 (50 ml. of each concentration). Fractions $(5 \mathrm{ml}$.) were collected and assayed for activity and the optical density at $280 \mathrm{~m} \mu$ determined. High titre fractions were pooled and dialysed against distilled water (pH 7·5).

\section{Analysis of bacteriocin}

Bacteriocin solution. Purified bacteriocin was dialysed against repeated changes of distilled water and evaporated to constant dry weight under reduced pressure over $\mathrm{P}_{2} \mathrm{O}_{5}$. The bacteriocin ( $4 \mathrm{I} \cdot 0 \mathrm{mg}$.) was then dissolved in distilled water, $\mathrm{pH} 7 \cdot 5(25 \mathrm{ml}$.).

Determination of carbon, hydrogen and nitrogen. This was done on a Perkin-Elmer model 240 elemental analyser by the National Chemical Research Laboratories of the South African Council for Scientific and Industrial Research.

Phosphate determination. Total inorganic phosphate was measured by the method of Knight \& Woody (1958).

Identification of carbohydrates. Two-dimensional thin-layer chromatography was done on silica gel $F_{254}$ plates (E. Merck AG, Darmstadt) with carbohydrates liberated from the bacteriocin (de Klerk \& Smit, 1967). The solvents used were: first dimension, propan-2-ol + ethylacetate + water $(4+3+2$, by vol.); second dimension, butan-I-ol + acetone + water $(5+4+\mathrm{I}$, by vol.). Authentic specimens of $\mathrm{L}(+)$ arabinose, $D(+)$ galactose, $\mathrm{D}(+)$ glucose and $\mathrm{D}(+)$ xylose (British Drug Houses, Ltd.; B.D.H.) were used as references. After development, the chromatograms were dried and sprayed with $p$-anisidine phosphate in ethanol (Mukherjee \& Srivastava, 1952).

Quantitative determination of carbohydrate components. A solution ( $\mathrm{I} \mathrm{ml}$.) containing carbohydrates (121 $\mu \mathrm{g}$.) liberated from bacteriocin was applied as a band to Whatman no. 54 paper $(46 \mathrm{~cm} . \times 57 \mathrm{~cm}$.) and developed by descending chromatography together with a blank paper with ethylacetate + acetic acid + water $(3+3+3$, by vol. $)$ for $\mathrm{Io} \mathrm{hr}$. The positions of the separated sugars on guide strips were revealed by the spray reagent and the corresponding areas excised from the experimental and blank chromatograms. Sugar and corresponding blank strips were quantitatively eluted with distilled water (Dent, 1947) and collected into measuring cylinders ( $5 \mathrm{ml}$.) which stood in an ice-bath and contained $0.4 \%(\mathrm{w} / \mathrm{v})$ I-naphthol in concentrated sulphuric acid (2.5 ml.). Elution was stopped when $\mathrm{I}$ ml. of solvent had been collected and was then assayed for sugar concentration (Devor, 1948) using $L(+)$ arabinose, $D(+)$ galactose, $D(+)$ glucose and $\mathrm{D}(+)$ xylose (B.D.H.) as standards.

Estimation of lipids. Bacteriocin (2.343 mg.) was hydrolysed with $6 \mathrm{~N}-\mathrm{HCl}(2 \mathrm{ml}$.) for $8 \mathrm{hr}$ at $100^{\circ}$ (Salton, 1953). Any liberated lipids were extracted with five volumes of a 
chloroform + methanol $(2+\mathrm{I}, \mathrm{v} / \mathrm{v})$ solution and the mixture centrifuged (2000 $\mathrm{g}$ for Io min.). The upper phase containing non-lipid impurities was removed and the lower chloroform phase which should contain lipid was freed of water-soluble impurities by diffusion into distilled water (2 1.) according to Sperry (1955). The diffusion was allowed to proceed for $72 \mathrm{hr}$ with frequent changes of water. The chloroform layer was adjusted to $5 \mathrm{ml}$. and samples ( $\mathrm{I} \mathrm{ml}$.) assayed by an ultramicro method for lipid content (Pande, Parvin Khan \& Venkitasubramanian, 1963) using palmitic acid (B.D.H.) as standard.

Methods for the determination of amino acids, hexosamine, nucleic acids and protein and electron microscopy techniques have been described (de Klerk \& Smit, 1967).

\section{Other investigations}

Sedimentation of bacteriocin. This was done at $56,100 \mathrm{rev} . / \mathrm{min}$. at $20^{\circ}$ in the AN-D rotor of a Spinco model $\mathrm{E}$ ultra-centrifuge. A $\mathrm{I} \cdot 6 \%(\mathrm{w} / \mathrm{v})$ purified bacteriocin solution in 0.1 M-sodium phosphate buffer, $\mathrm{pH} 7 \cdot 6$, was used in a $12 \mathrm{~mm}$. standard cell and photographs taken at $8 \mathrm{~min}$. intervals using schlieren optics.

Action of urea on bacteriocin. The action of $6 \mathrm{M}$-urea was tested as described (de Klerk \& Smit, 1967).

Oxidation and reduction of bacteriocin. Oxygen was bubbled through bacteriocin solution for $30 \mathrm{~min}$. at room temperature. Solutions of bacteriocin were also treated with hydrogen peroxide, bromine, potassium permanganate, sodium sulphite and sodium borohydride (final concentration Io mM).

Action of sulphydryl reagents on bacteriocin. Bacteriocin solution was treated for $30 \mathrm{~min}$. at room temperature with $N$-ethyl-maleimide, chloromercuribenzene- $p$ sulphonate, iodoacetamide and oxidized glutathione dissolved in $100 \mathrm{~mm}$-sodium phosphate buffer, $\mathrm{pH} \mathbf{7 \cdot 2}$, and used in a final concentration of $10 \mathrm{mM}$.

Action of enzymes on bacteriocin. Bacteriocin solution $(0.3 \mathrm{ml} ., 0.16 \%(\mathrm{w} / \mathrm{v}))$ was dialysed against each of the following buffers and then treated with the enzyme in parentheses; 0.I M-sodium phosphate buffer, $\mathrm{pH} 7.5$ (trypsin); 0.I M-sodium citrate buffer, $\mathrm{pH} 2.2$ (pepsin); 0. I M-tris-HCl buffer, $\mathrm{pH} 9.0$ (pronase) and $0.1 \mathrm{M}$-ammonium acetate, $\mathrm{pH} 7.0$ (lysozyme). Incubations were carried out with enzyme $(0.3 \mathrm{ml}$., $0.01 \%$ $(\mathrm{w} / \mathrm{v}))$ for $4 \mathrm{hr}$. Control experiments were done without enzyme and bacteriocin titres determined.

\section{RESULTS}

Mutants of strain NM 107 resistant to bacteriocin 336 but susceptible to bacteriocins produced by strains NCTC 2818 and NM 38 were readily obtained. Despite numerous attempts, no resistant mutants of strain NM I 6 were found. Strain NM I 6 was used in the previous (Coetzee, 1967) unsuccessful attempt to obtain mutants resistant to bacteriocin 336. It is well known that strains differ in the rate with which they give rise to bacteriocin-resistant mutants (Frédéricq, 1948; Paterson, 1965). Attempts to transfer bacteriocinogeny to strains NM I 54 str-r and NCTC 5845 str- $r$ were unsuccessful. One thousand clones of each strain were tested. There is a possibility that transfer at very low rates may have been missed. Coetzee (I964) reported the transfer of col D and col J from Escherichia coli CA 23 and paracolon strain CA 62 respectively to Providence strain NCTC 9295. No more than $\mathrm{IO}^{-3}$ of acceptor bacteria became colicino- 
genic. Ozeki et al. (1962) reported transfer of col K from E. coli $\mathrm{K} 49$ at a rate of $10^{-4} /$ acceptor cell of Salmonella typhimurium.

\section{Removal of bacteriocinogenic factor by acridine orange}

Thirty-five colonies which arose after treatment of strain MR 336 with each particular combination of acridine orange and $\mathrm{pH}$ were tested for bacteriocinogeny. Thirty micrograms acridine orange per millilitre at $\mathrm{pH} 7.45$ rendered 23 of the $35(65 \cdot 7 \%)$ clones non-bacteriocinogenic. Neighbouring combinations of dye and $\mathrm{pH}$ produced little or no loss of bacteriocinogeny and also in the absence of acridine orange no loss occurred. The non-bacteriocinogenic clones showed the same phage susceptibility pattern as strain MR 336 (J. N. Coetzee, unpublished observations).

\section{Isolation of pure bacteriocin}

Ultraviolet light induced $6 \mathrm{hr}$ broth cultures of strain MR $336 \mathrm{had}$ bacteriocin titres of about $\mathrm{I} / \mathrm{I} 6$ in the supernatant. The activity of crude bacteriocin solutions decreased upon storage and was lower than expected in ammonium sulphate precipitates. This inactivation could be prevented by the addition of $50 \mathrm{~mm}$-sodium sulphite and I mM-EDTA immediately after the organisms had been deposited and is thought to be due to oxidation of the bacteriocin. Subsequent manipulations were carried out in the reducing environment or with suitable precautions against air oxidation. The diffusate medium did not contain molecules with a weight exceeding 10,000 (Leggett Bailey, 1962) and facilitated separation of the non-diffusible bacteriocin from broth constituents by dialysis and chromatography on Sephadex columns. Ten litres of crude bacteriocin were precipitated with ammonium sulphate and the precipitate dissolved in $25 \mathrm{ml}$. yielded a titre of $\mathrm{I} / 4096$; this represented a recovery of $60-70 \%$. Further purification was accomplished on Sephadex (Fig. I) and finally on calcium phosphate gel (Fig. 2). Repassage of pure bacteriocin through either column yielded a single peak. Ultracentrifugation of the purified bacteriocin resulted in a single peak with an $S_{20, w}$ value of $4 \cdot 0$.

\section{Chemical composition}

The bacteriocin consists of protein $87.9 \%$ and carbohydrate $8.1 \%$. This accounts for $96.0 \%$ of the solids in the bacteriocin solution. This figure is about the limit of the expected recovery, although a small fraction of solids may still be unaccounted for. An elemental analysis yielded $\mathrm{C}, 46.6 ; \mathrm{H}, 6.6 ; \mathrm{N}, 13.6 \%$. The amino acids present in the protein fraction are listed in Table I. Acidic amino acids predominate with a trace of allo-isoleucine also present. The carbohydrate fraction contains (mole $\%$ ): arabinose, 5.8; galactose, 27.6; glucose, 63.0; and xylose, 3.6. No lipids, nucleic acids, hexosamine or phosphorus were detected.

\section{Properties of the bacteriocin}

Purified bacteriocin was a fluffy, white powder which showed only amorphous material under electron microscopic examination. It has a solubility of $I \cdot 8^{4} \%(w / v)$ in water at $\mathrm{pH} 7.5$. The material could be precipitated by trichloroacetic acid or perchloric acid and this also testified to its protein nature. Activity of the bacteriocin was completely lost upon oxidation with oxygen, hydrogen peroxide, bromine or potassium permanganate and the activity of solutions stored in open containers 
slowly decreased due to air oxidation. With precautions against oxidation a solution of bacteriocin retained full activity in the cold for more than three months. Reducing agents like sodium sulphite and sodium borohydride were unable to reactivate oxidized

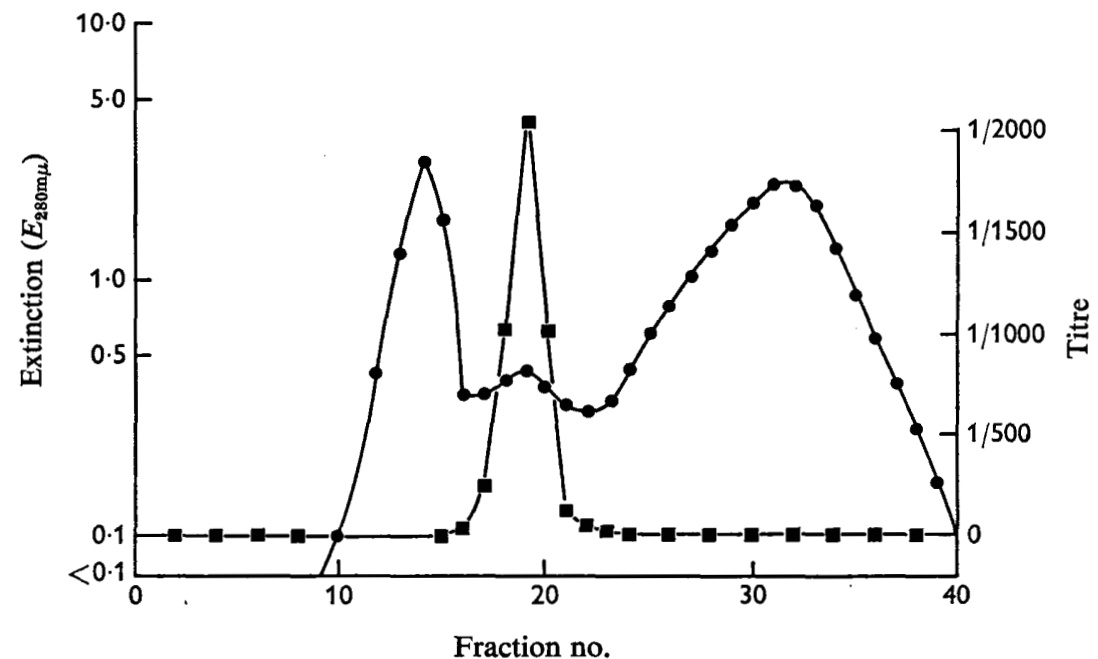

Fig. I. Chromatography of ammonium sulphate precipitated bacteriocin 336 on Sephadex G 200. A $3 \mathrm{ml}$. sample (titre $1 / 4096$ ) was applied to the column and eluted with $0 \cdot \mathrm{I} \mathrm{M}-\mathrm{KCl}+$ 0.05 M-tris- $\mathrm{HCl}+0.05 \mathrm{M}$-sodium sulphite + 0.001 M-EDTA buffer (pH 7.6). Fractions ( $5 \mathrm{ml}$.) were collected and assayed for -0 , extinction $\left(E_{280 \mathrm{~m} \mu}\right)$ and $\mathrm{E}_{-}-\mathrm{G}$, inhibitory activity.

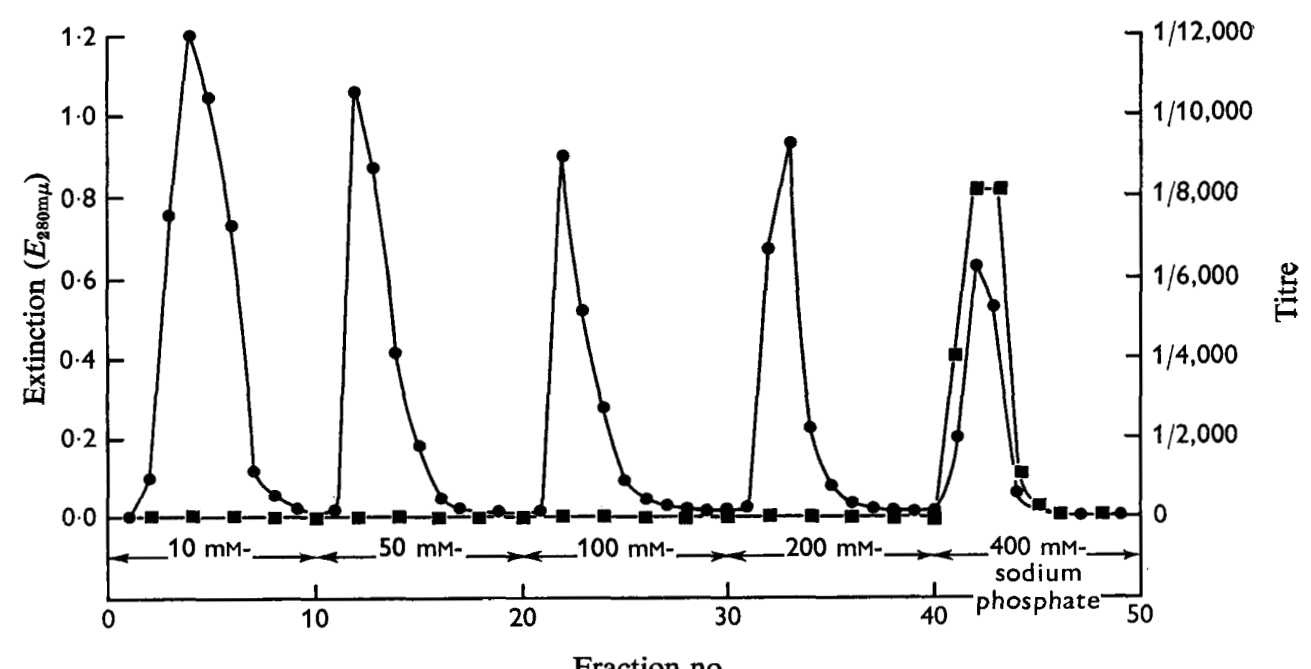

Fig. 2. Chromatogaphy of bacteriocin 336 on calcium phosphate gel. Partially purified bacteriocin was concentrated and dialysed against 10 mM-sodium phosphate buffer, $\mathrm{pH} 6 \cdot 8$. A ro ml. sample (titre $\mathrm{r} / 4096$ ) was applied to the column and stepwise elution carried out with sodium phosphate buffer (pH 6.8) at concentrations of 10, 50, 100, 200 and $400 \mathrm{~mm}$. Fractions were collected and assayed for $\longrightarrow-$, extinction $\left(E_{280 \mathrm{~m} \mu}\right)$, and $\square-\square$, inhibitory activity. 
material. Aqueous solutions of the bacteriocin lost all activity above $60^{\circ}$ for $30 \mathrm{~min}$. Activity was destroyed by pepsin, pronase and trypsin, but was unaffected by lysozyme. Treatment with reagents which react with sulphydryl groups did not affect activity. Separation of the protein moiety by treatment with phenol (Goebel \& Barry, 1958) resulted in an inactive protein preparation. Treatment with urea decreased activity by half.

Table I. Amino acid composition of the protein fraction of bacteriocin 336

$\begin{array}{lccc}\text { Residues/I000 } & \begin{array}{c}\text { Amino acid } \\ \text { total amino } \\ \text { acid residues } \\ \text { Lysine }\end{array} & \begin{array}{c}\text { Amino acid } \\ \text { I06.6 }\end{array} & \begin{array}{c}\text { Residues/I000 } \\ \text { total amino } \\ \text { acid residues }\end{array} \\ \text { Histidine } & 20 \cdot 0 & \text { Alanine } & 85 \cdot 6 \\ \text { Arginine } & 48 \cdot 0 & \text { Valine } & 63 \cdot 0 \\ \text { Aspartate } & 124 \cdot 6 & \text { Methionine } & \text { I I.8 } \\ \text { Threonine* } & 53 \cdot 7 & \text { Allo-isoleucine } & \text { Trace } \\ \text { Serine* } & 51 \cdot 2 & \text { Isoleucine } & 57 \cdot 3 \\ \text { Glutamate } & 129 \cdot 8 & \text { Leucine } & 67 \cdot 4 \\ \text { Proline } & 50 \cdot 5 & \text { Tyrosine } & 23 \cdot 0 \\ \text { Glycine } & 75 \cdot 5 & \text { Phenylalanine } & 32 \cdot 0 \\ & * \text { Corrected for loss during hydrolysis. } & \end{array}$

\section{DISCUSSION}

The fact that acridine orange can eliminate bacteriocinogeny from $65.7 \%$ of cells under optimal conditions favours an autonomous cytoplasmic existence of the factor(s) which control bacteriocin production in Proteus morganii strain MR 336 (Hirota, 1960; Clowes, Moody \& Pritchard, 1965). Elimination is confined to a very limited range of concentration and $\mathrm{pH}$ of the dye, but restrictions of this kind have been noted with elimination of plasmids like the F factor (Hirota, 1960), col V (Kahn \& Helinski, 1964) and $R$ factors (Watanabe \& Fukasawa, 196I). The lack of transmissibility of the bacteriocinogenic factor may be difficult to reconcile with a cytoplasmic existence. The factor may, however, resemble the $c o l \mathrm{E}_{1}-\mathrm{K} 30$ factor which is not independently transmissible but can be eliminated by thymine starvation (Clowes et al. 1965) and is thought to be a plasmid (Nomura, 1967).

Bacteriocin 336 is a glycoprotein. Extraction of the protein moiety of the bacteriocin with phenol (Goebel \& Barry, 1958) destroyed all activity and it was also inactivated by treatment with proteolytic enzymes. As the phenol treatment could denature the protein in addition to separating the carbohydrate the activity of the bacteriocin may reside exclusively in the protein moiety. Colicin K-K 235 was isolated in the form of a lipoglycoprotein complex (Goebel \& Barry, 1958), the activity of which was shown to reside in the protein moiety. Reeves (1963) found colicin E 2-CA 42 (also known as colicin F (Reeves, 1963)) to consist of $75 \%$ protein and $10 \%$ carbohydrate and our bacteriocin has a similar composition. Herschman \& Helsinki (1967) claim that colicins E 2-P 9 and E 3-CA 38 are proteins composed exclusively of amino acids. These differences in the composition of colicin $\mathrm{E} 2$ may be due to the use of different strains, culture conditions or methods of isolation (Nomura, 1967). Bacteriocin 336 does not contain sulphydryl amino acids and the glycoprotein is unaffected by reagents which react with sulphydryl groups. The sensitivity of the bacteriocin towards oxidation was 
therefore unexpected, as it has not been shown to contain oxidizable material under conditions employed. Ninety-six per cent of the solids have been accounted for and the presence of an unsaturated compound, possibly lipid, the oxidation of which leads to inactivation of the bacteriocin, may account for the balance. Reeves (1963) also noted that colicin E 2-CA 42 lost activity upon prolonged dialysis and during vacuum distillation. This loss could also have been due to oxidation. No lipid moiety was detected in bacteriocin 336 despite the use of a drastic hydrolytic technique and a sensitive assay. However, Nowotny (1963) found that all hydrolytic methods for the liberation of lipids leave some carbohydrates bound to complex lipids and severe hydrolysis partially destroys the lipid fraction.

This work was aided by grants from the South African Council for Scientific and Industrial Research to J.N.C.

\section{REFERENCES}

Clowes, R. C., Moody, E. E. M. \& PrITChard, R. H. (1965). The elimination of extrachromosomal elements in thymineless strains of Escherichia coli. Genet. Res. 6, 147.

Coetzee, H. L., De Klerk, H. C., Coetzee, J. N. \& Smit, J. A. (I968). Bacteriophage tail-like particles associated with intra-species killing of Proteus vulgaris. J. gen. Virol. 2, 29.

CoetzeE, J. N. (1964). Transmission of colicinogeny to Providence strains. Nature, Lond. 203, 897.

Coetzee, J. N. (1967). Bacteriocinogeny in strains of Providence and Proteus morganii. Nature, Lond. $213,614$.

DE KLERK, H. C. \& SmIT, J. A. (1967). Properties of a Lactobacillus fermenti bacteriocin. J. gen. Microbiol. 48, 309.

Dent, C. E. (1947). The amino-aciduria in Fanconi syndrome. A study making extensive use of techniques based on paper partition chromatography. Biochem. J. 4r, 240.

DEVOR, A. W. (1948). Improved method of preparing sulfonated I-naphthol for carbohydrate tests. Analyt. Chem. 24, 1626.

Endo, H., Ayabe, K., Amako, K. \& Takeya, K. (1965). Inducible phage of Escherichia coli 15. Virology 25, 469.

FrédéricQ, P. (1948). Antibiotiques reciproques chez les Enterobacteriaceae. Rev. belge Path. Méd. exp. I9 (suppl. 4), I.

FrédéRICQ, P. (I954). Transduction génétique des propriétés colicinogènes chez Escherichia coli et Shigella sonnei. C. r. Séanc. Soc. Biol., Paris 148, 399.

Goebel, W. F. \& BARRY, G. T. (1958). Colicine K. II. The preparation and properties of a substance having colicine K activity. J. exp. Med. 107, 185 .

Herschmann, H. R., \& Helsinki, D. R. (1967). Purification and characterization of colicin $E_{2}$ and colicin $\mathrm{E}_{3}$.J. biol. Chem. 242, 5360.

HinsDILL, R. D. \& GoEBel, W. F. (I966). Colicine K. VII. The transfer of type K colicinogeny to Shigella sonnei. J. exp. Med. 123,881 .

HiRota, Y. (1960). The effect of acridine dyes on the mating type factors in Escherichia coli. Proc. natn. Acad. Sci., U.S.A. 46, 57.

HollaNd, I. B. (196I). The purification and properties of megacin, a bacteriocin from Bacillus megaterium. Biochem. J. 78, 64I.

Ishin, S., Nish, Y. \& Egami, F. (1965). The fine structure of a pyocin. J. molec. Biol. 13, 428.

KAHN, P. \& HelinsKI, D. R. (1964). Relationship between colicinogenic factors $E_{1}$ and V and on F factor in Escherichia coli. J. Bact. 88, 1573.

KNIGHT, C. A. \& WoOdy, B. R. (1958). Phosphorus content of tobacco mosaic virus. Arch. Biochem. Biophys. 78, 460 .

Lederberg, J. (1952). Cell genetics and hereditary symbiosis. Physiol. Rev. 32, 403.

LegGett BalleY, J. (1962). Techniques in Protein Chemistry. London: Elsevier Publishing Company.

MukHERJEe, S. \& SRIVASTAVA, H. C. (1952). Improved spray reagent for the detection of sugars. Nature, Lond. 169, 330.

Nomura, M. (1967). Colicins and related bacteriocins. A. Rev. Microbiol. 21, 257. 
NowotNy, A. (1963). Relation of structure to function in bacterial $O$ antigens. II. Fractionation of lipids present in Boivin-type endotoxin of Serratia marcescens. J. Bact. 85, 427.

OzeKI, H. \& HowARTH, S. (I96I). Colicine factors as fertility factors in bacteria: Salmonella typhimurium strain LT 2. Nature, Lond. 190, 986.

OZeKI, H., STOCKER, B. A. D. \& SMTTH, S. M. (1962). Transmission of colicinogeny between strains of Salmonella typhimurium grown together. J. gen. Microbiol. 28, 671.

Pande, S. V., Parvin Khan, R. \& Venkitasubramanian, T. A. (1963). Microdetermination of lipids and serum total fatty acids. Analyt. Biochem. 6, 415 .

Paterson, A. C. (1965). Bacteriocinogeny and lysogeny in the genus Pseudomonas. J. gen. Microbiol. 39, 295.

RegVes, P. R. (1963). Preparation of a substance having colicine F activity from Escherichia coli CA 42. Aust. J. exp. Biol. 41, 163.

SALton, M. R. J. (1953). Studies of the bacterial cell wall. IV. The composition of the cell walls of some Gram-positive and Gram-negative bacteria. Biochim. biophys. Acta 1o, 512.

Sandoval, H. K., Reilly, H. C. \& TANDLER, B. (1965). Colicin 15: possibly a defective bacteriophage. Nature, Lond. 205, 522.

SMITH, S. M. \& STOCKeR, B. A. D. (1962). Colicinogeny and recombination. Br. med. Bull. 18, 46.

SMrth, S. M., OzeKI, H. \& STocker, B. A. D. (1963). Transfer of col $\mathrm{E}_{1}$ and col $\mathrm{E}_{2}$ during highfrequency transmission of col I in Salmonella typhimurium. J. gen. Microbiol. 33, $23 \mathrm{I}$.

SPERRY, W. M. (1955). In Methods of Biochemical Analysis. Ed. by Glick, D. Interscience Publishers. Vol. I, p. 83 .

Tiselius, A., HJertén, S. \& LeVIN, O. (1956). Protein chromatography on calcium phosphate columns. Arch. Biochem. Biophys. 65, I32.

Watanabe, T. \& Fukasawa, T. (1961). Episome mediated transfer of drug resistance in Enterobacteriaceae. II. Elimination of resistance factors with acridine dyes. J. Bact. 8r, 679. 